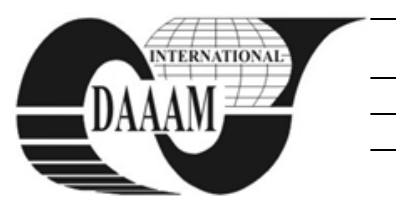

\title{
ON THE REAMING OF AUSTENITIC STEELS WITH COATED CERMETS
}

\author{
PISKA, M[iroslav] \& SLANY, M[artin]
}

\begin{abstract}
High effective cermet reaming of austenitic steel with cutting speeds $40-100 \mathrm{~m} / \mathrm{min}$, feed per revolution $0.2-0.8 \mathrm{~mm}$ and flood cooling has been analysed. A CNC machining sequence including solid carbide drilling, a semi-finishing carbide boring and cermet reamer finishing of the stainless steel AISI 316L were used and analysed. The results show a very effective cutting with surface rougness Ra bellow $1.0 \mathrm{um}$, with high accuracy of IT 5 and convenient specific energy.
\end{abstract}

Key words: reaming, austenite, cermet, cooling, nanocomposite

\section{INTRODUCTION}

In the second half of the 20th century monolithic cutting tools were replaced with so-called indexable inserts and the reaming heads were innovated with several brazed cutting edges and guiding parts. The new designs helped to produce very effective cutting tools at reasonable prices. The producers of precise tools today have to design cutting tools with a quick exchange that guarantee a high production dimensional stability and consistent high quality as well as consistent high quality. A new strategy for reaming with minimum quantity lubrication (MQL) has been studied recently (De Chiffre et al., 2008-9) with an excellent dimensional and quality evaluation (Muller, 2009). New cermet reamers have been studied quite recently (Slany, 2011). The basic advantages of the finishing tools can be high-lighted as follows:

- the reamers are particularly recommended for reaming materials with tensile strength ranging from $400 \mathrm{MPa}$ to 1000 $\mathrm{MPa}$;

- the tools prevail with high productivity due to high cutting speed from 100 up to $240 \mathrm{~m} / \mathrm{min}$ (4-10 times higher than standard carbide reamers);

- a good surface quality, shape and diameter accuracy is produced for steels with tensile strength below $600 \mathrm{MPa}$;

- a smooth roughness (surface quality is improved by high stiffness of cermet head and carbide shank with high Young's module);

- chips are intensively removed from the cutting edge by means of coolant flow through inner channels;

- high stability of the manufacturing process and life time due to no affinity with machined material;

- high performance/price ratio - due to reduction of WC and substitutions of $\mathrm{TiN}, \mathrm{TiC}$ and $\mathrm{Ti}(\mathrm{C}, \mathrm{N})$ phases,

- advanced design of the modern reamer heads as an assembly set makes it very competitive due to a delivery time of 24 hours from the producer to the user.

\section{THEORY OF FINISHING WITH REAMERS}

According to the ISO 3002-4 cutting design (3 cutting flutes and 3 guides) - Fig. 1 - the reamer head is loaded with several normal and tangential force components, resulting in two measureable variables - thrust force $\mathrm{F}_{\mathrm{f}}$ and torque moment $\mathrm{M}_{\mathrm{t}}$, integrating all the contributions from the cutting and interface friction:

$$
\begin{array}{r}
F_{f}=\sum_{i=1}^{z} F_{f i}+\sum_{i=1}^{g} F_{A i} \\
M_{t}=\sum_{i=1}^{z} M_{c i}+\sum_{i=1}^{g} M_{f i},
\end{array}
$$

where the first members in the equations represent mainly the cutting parts and the second the passive (friction) shares. The individual torque moments can be derived from the instantaneous forces and appropriate radii. The other useful variable - specific energy of reaming - can be simplified to equation (3), where parameters of chip-cross section and cutting conditions are also included:

$$
e_{c i}=\left(\frac{M_{c i} \cdot n}{9.55}+\frac{F_{f i} \cdot n \cdot f}{6.10^{4}}\right) \cdot \frac{120}{\pi \cdot n \cdot f \cdot a_{p} \cdot\left(D-a_{p}\right)}
$$

\section{EXPERIMENTAL WORKS}

The material of the workpiece - Table 1 - was the corrosion resistant steel, DIN 1.4404, X2CrNiMo1732 (equivalent standard AISI 316L), technical delivery terms EN 10088, dimensional and shape deviation tolerances according to EN 9445 with the austenitic structure, ground surface. These steel grades have increased corrosion resistance in chemical environments and are used for structural components, instruments and apparatus in the chemical industry. The blank rods $\varnothing 30 \mathrm{~mm}$ and 3,000 $\mathrm{mm}$ in length were machined to the $\varnothing 29$ $\mathrm{mm}$ and $15 \mathrm{~mm}$ in length.

The workpieces were mounted to a special precise fixture with a ground screw acting on the top of the specimen wall to prevent radial deflections. The whole assembly was coaxially fixed to the dynamometer KISTLER 9272, fully controlled with a computer.

The dynamometer set was placed into the new CNC machining centre MCV 1210 (ZPS TAJMAC, share company, Zlin) controlled with the Sinumerik 840D. Kistler dynamometer 9272, charge amplifiers 9011 and the Dynoware program for force and torque analyses of the sample loading were used. The sampling rate $3 \mathrm{kHz}$, low-pass filter and the long time constant were set for all data acquisition. A special CNC programme was written for automatic control of the reaming operation and the canned cycles.

The following technological sequence of tools was set:

- short helical carbide center drill ø6.4 mm, Guhring, Art. Nr. 736, HSK - A63 D17356) for the center hole drilling,

- solid carbide drill $\varnothing 8 \mathrm{~mm}$, thermogrip Bilz - HSK A63 68 $\left(\mathrm{v}_{\mathrm{c}}=60 \mathrm{~m} / \mathrm{min}, \mathrm{f}=0.1 \mathrm{~mm}\right)-$ the pilot hole,

- whole carbide drill M44 ø17 mm, tool holder Weldon HSK A63 D18 A80 CFB-01, $\left(\mathrm{v}_{\mathrm{c}}=60 \mathrm{~m} / \mathrm{min}, \mathrm{f}=0.1 \mathrm{~mm}\right)-$ boring operation, 
- monolithic boring bar HF, carbide inserts CCMT 060204 $ø 17.7+0.05 \mathrm{~mm}$, tool holder HSK A63 D16 A100 - DFB01 $\left(\mathrm{v}_{\mathrm{c}}=60 \mathrm{~m} / \mathrm{min}, \mathrm{f}=0.1 \mathrm{~mm}\right)$,

- countersink $90^{\circ} ø 30$ mm, DIN 335, Guhring, Art. Nr. 327 tool holder - thermogrip Bilz - HSK A63 ø20

- monolithic cermet reaming head MT3 HAM FINAL Ltd., $ø 17.814 \mathrm{~mm}$, coated with the nanocomposite super-nitride (Ti0.4,Al0.6)N, CemeCon HYPERLOX, gripped in the carbide thermogrip HAM-FINAL. The Fuchs Oil emulsion ECOCOOL 68 CF2 (10\% concentration, 60 bars in pressure, flood intensity $50 \mathrm{l} / \mathrm{min}$ ) and outer system of cooling with an emulsion reservoir of 1,200 litres for the machining were used. The temperature of the cooling fluid as measured during all machining and it was changing in the range of $20-25^{\circ} \mathrm{C}$. Cutting speed $\mathrm{v}_{\mathrm{c}}=40-100 \mathrm{~m} / \mathrm{min}, \mathrm{ap}=0.057 \mathrm{~mm}, \mathrm{f}=0.2-0.8 \mathrm{~mm}$ were tested. Two reamer heads have been tested for statistically pooled data assessment.

\begin{tabular}{|c|c|c|c|c|c|c|}
\hline \multicolumn{7}{|c|}{ Chemical composition (weight \%) } \\
\hline $\mathrm{C}$ & $\mathrm{Si}$ & $\mathrm{Mn}$ & \multicolumn{2}{|c|}{$\mathrm{P}$} & \multicolumn{2}{|c|}{$\mathrm{Ni}$} \\
\hline 0.016 & 0.39 & 1.4 & \multicolumn{2}{|c|}{0.027} & \multicolumn{2}{|c|}{11.21} \\
\hline $\mathrm{Cr}$ & Mo & $\mathrm{S}$ & \multicolumn{2}{|c|}{$\mathrm{N}$} & \multicolumn{2}{|c|}{$\mathrm{Fe}$} \\
\hline 17.31 & \multicolumn{2}{|c|}{2.11} & & & 0.052 & rest \\
\hline \multicolumn{6}{|c|}{ Mechanical properties } & \\
\hline \multicolumn{2}{|c|}{$\begin{array}{l}\text { Yield point } \\
\mathrm{R}_{\mathrm{e}}[\mathrm{MPa}]\end{array}$} & \multicolumn{2}{|c|}{$\begin{array}{c}\text { Tensile strength } \\
\mathrm{R}_{\mathrm{m}}[\mathrm{MPa}]\end{array}$} & \multicolumn{2}{|c|}{$\begin{array}{l}\text { Dilatability - } \\
\mathrm{A}_{80} \text { min. [\%] }\end{array}$} & \\
\hline \multicolumn{2}{|c|}{$240-270$} & \multicolumn{2}{|c|}{$530-680$} & \multicolumn{2}{|r|}{40} & \\
\hline
\end{tabular}

Tab. 1. Composition and properties of the tested material

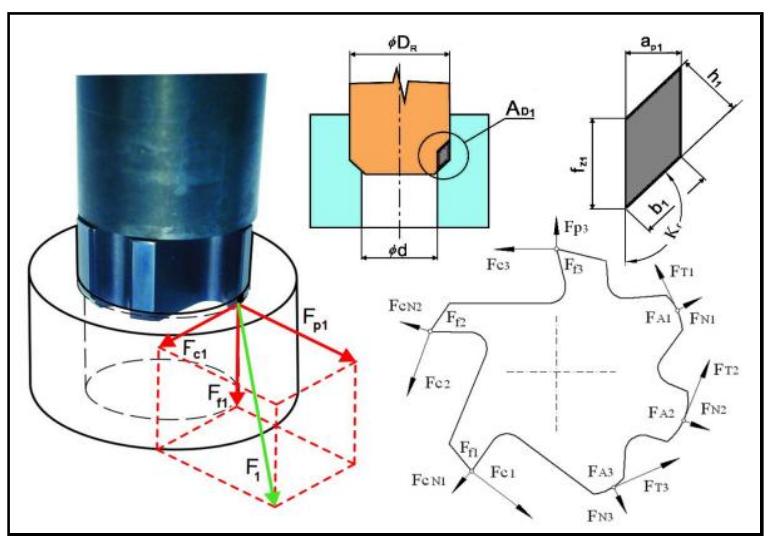

Fig. 1. A model of a reamer force loading, a chip cross-section

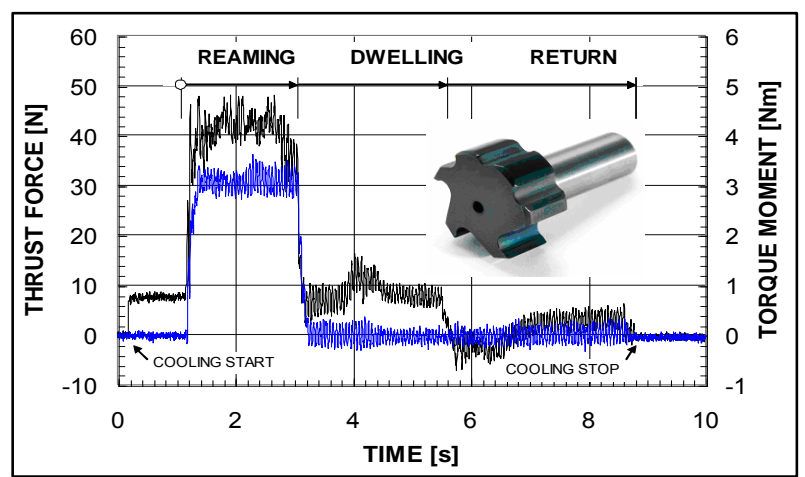

Fig. 2. Time series of the measured torque and thrust force

The statistically assessed results can be seen in Fig. 3, 4 .

\section{CONCLUSION}

The nanocomposite super-nitride (Ti0.4, A10.6)N coating effeciently protected the reamer heads for finishing of austenitic stainless steels. The accuracy of IT5, roughness Ra<1.0 $\mu \mathrm{m}$ and other benefitial phenomena can be achieved even in very intensive cutting conditions for machining of the austenitic stainless steel. However, a very effective flood cooling with enriched cutting emulsion should be used and analyzed more.

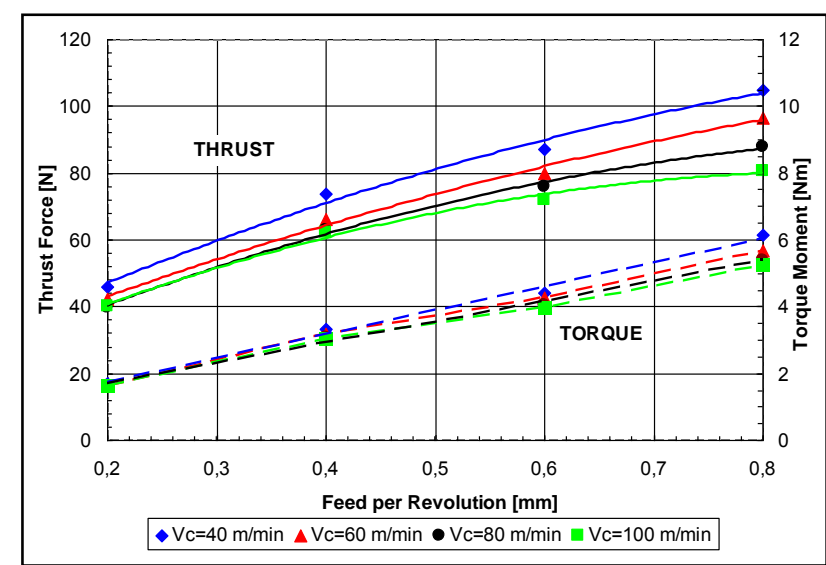

Fig. 3. Torque and thrust as functions of feeds and cutting speeds when reaming (pooled average values)

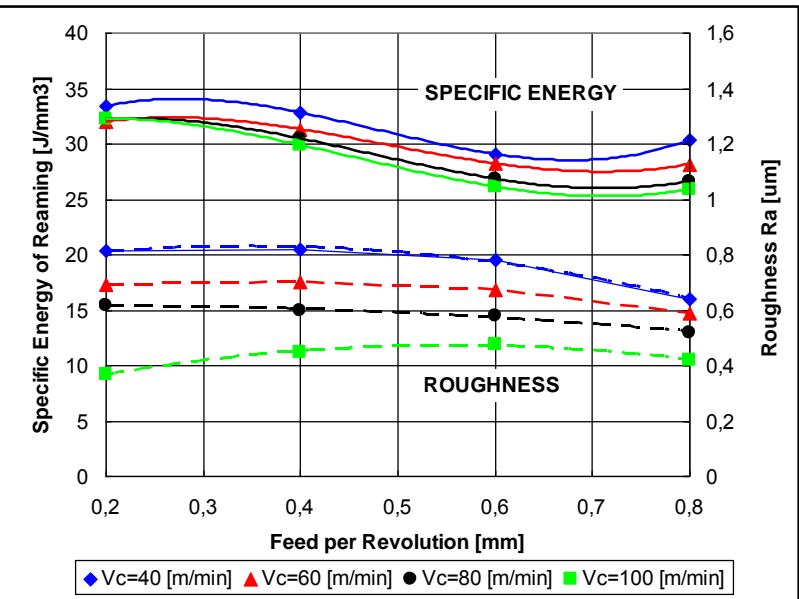

Fig. 4. Specific energy and roughness as functions of feeds and cutting speeds when reaming (pooled average values)

\section{ACKNOWLEDGEMENT}

This research work was supported by the BUT, Faculty of Mechanical Engineering, Brno, Specific research 2010, with the grant "Congruent technologies of very precise machining of shaped surfaces", FSI-S-10-61, ID 361.

\section{REFERENCES}

De Chiffre, L., Tosello, G., Piska, M. \& Müller, P. (2008). Investigation on Capability of Reaming Process using Minimal Quantity Lubrication. Proceedings of The Swedish Production Symposium, SPS08, pp: 85-92, 2008, Royal Institute of Technology (KTH) (Stockholm, Sweden) In: Swedish Production Symposium (SPS08)

De Chiffre, L., Tosello, G., Piska, M. \& Muller, P. (2009). Investigation on Capability of The Reaming Process Using Minimal Quantity Lubrication. CIRP Journal of Manufacturing Science and Technology, Volume 2, Issue 1, January 2009, pp. 47-54. ISSN 1755-5817

Müller, P. \& De Chiffre, L. (2009). Investigation on Hole Manufacture in 42CrMo4 Steel Using 3-flute Carbide Drills and 6-flute Cermet Reamers. SPS 09, pp. 438-446, Proceedings of The Swedish Production Symposium, 2009, Gothenburg

Slany, J., Polzer, A. \& Píška, M. (2011) On the effective reaming of austenitic steels On the effective reaming of austenitic steels with cermet reamers and flood cooling. In: Proceedings of the SPS 11 The 4th International Swedish Production Symposium, The Swedish Production Academy, pp.228-234, Lund

*** ISO 3002-4 (Basic Quantities in Cutting and Grinding -Part 4: Forces, energy, power). 